\title{
Pathogenicity of Beauveria bassiana and production of cuticle-degrading enzymes in the presence of Diatraea saccharalis cuticle
}

\author{
Virgínia Michelle Svedese ${ }^{1 *}$, Patricia Vieira Tiago ${ }^{1}$, Jadson Diogo Pereira Bezerra ${ }^{1}$, Laura \\ Mesquita Paiva ${ }^{1}$, Elza Áurea de Luna Alves Lima ${ }^{1}$, Ana Lúcia Figueiredo Porto ${ }^{2}$ \\ 1 Departamento de Micologia, Laboratório de Controle Biológico, Universidade Federal de Pernambuco, Avenida \\ Professor Nelson Chaves, s/n, Cidade Universitária, CEP: 50670-420, Recife, Pernambuco, Brazil. \\ ${ }^{2}$ Departamento de Morfologia e Fisiologia Animal, Laboratório de Tecnologia de Bioativos, Universidade Federal Rural \\ de Pernambuco - Rua Dom Manoel de Medeiros, s/n, Dois Irmãos - CEP: 52171-900 - Recife, Pernambuco, Brazil.
}

Accepted 17 October, 2013

\begin{abstract}
The sugarcane borer, Diatraea saccharalis, is one of the worst pests in Brazilian sugarcane crop, causing high levels of financial losses every year. Beauveria bassiana is an entomopathogenic fungus widely used in the biological control of several agricultural pests. The aims of this study were to: (1) evaluate the pathogenicity of $B$. bassiana strains against $D$. saccharalis (2) investigate the production of proteases and chitinase by $B$. bassiana in the presence of the cuticle of sugarcane borer; and, (3) evaluate the relation between the production of enzymes and pathogenicity of the strains. All isolates tested were pathogenic to $D$. saccharalis and the mortality ranged from 36 to $88 \%$. The production of enzymes was higher in the medium containing cuticle, showing that the process is stimulated by specific components found in the cuticle of the host. Pr1 activity was higher than Pr2 and both were produced at $24 \mathrm{~h}$. The highest production of chitinase was obtained at $96 \mathrm{~h}$ of culture for all strains tested. Levels of specific cuticle-degrading enzymes such as proteases correlated positively with specific virulence parameters. B. bassiana URM2915 showed promising features to be used in a biological control program of $D$. saccharalis.
\end{abstract}

Key words: Biological control, sugarcane, subtilisin-like protease, trypsin-like protease, chitinase.

\section{INTRODUCTION}

Sugarcane (Saccharum officinarum L.) is an important source of sugar and alcohol in the Brazilian economy. However, part of the crop is lost due to the action of a number of insect pests, of which the borer Diatraea saccharalis Fabricius (Lepidoptera: Crambidae) is one of the most important (Gallo et al., 2002; Oliveira et al., 2008). Due to its cryptic lifestyle, conventional control measures by deploying chemical insecticides targeted at the larvae are ineffective.

An alternative to chemical control is the use of entomo- pathogenic fungi, such as Beauveria bassiana (Balsamo) Vuillemin and Metarhizium anisopliae (Metschnikoff) Sorokin. These fungi are widely used as biocontrol agents for a number of insect pests (Lacey, 2001; Hajek and Delalibera, 2010) and the efficiency of $B$. bassiana has already been proven against a number of Lepidoptera, such as Castnia licus Drury (Alves et al., 2002), Ostrinia nubilalis Hübner (Lewis et al., 2002), Plutella xylostella L. (Silva et al., 2003), Spodoptera frugiperda Smith (Vijayavani et al., 2009) and 
Table 1. Mortality (\%) of Diatraea saccharalis larvae at seven days after application of different strains of Beauveria bassiana.

\begin{tabular}{cllc}
\hline Access number & Insect host of origin & Site of origin & Mortality $^{\mathrm{a}}(\%) \pm$ SD \\
\hline URM2912 & Cyclonella sanguinea (Coleoptera) & Paraná/BR & $42 \pm 3.42 \mathrm{c}$ \\
URM2915 & Nezara viridula (Hemiptera) & Paraná/BR & $88 \pm 3.8 \mathrm{a}$ \\
URM2916 & Coleoptera & Brasília/BR & $76 \pm 4.2 \mathrm{ab}$ \\
URM2920 & Anticarsia gemmatalis (Lepidoptera) & Brasília/BR & $68 \pm 4.5 \mathrm{~b}$ \\
URM2921 & Lebia concinna (Coleoptera) & Paraná/BR & $84 \pm 5 \mathrm{a}$ \\
URM2923 & Deois flavopicta (Homoptera) & Paraná/BR & $76 \pm 4.7 \mathrm{ab}$ \\
URM2924 & Deois flavopicta (Homoptera) & Brasília/BR & $36 \pm 3.5 \mathrm{~d}$ \\
URM2930 & Euschistus heros (Hemiptera) & Paraná/BR & $79 \pm 5 \mathrm{ab}$ \\
URM3447 & Castnia licus (Lepidoptera) & Pernambuco/BR & $86 \pm 4.5 \mathrm{a}$ \\
URM4548 & Diabrotica speciosa (Coleoptera) & Buenos Aires/ARG & $46 \pm 5.1 \mathrm{c}$ \\
Control & & & $5.4 \pm 1 \mathrm{e}$ \\
\hline
\end{tabular}

${ }^{a}$ Mean followed by the same letter are not significantly different in the Tukey test at $5 \%$ probability. Original data, for statistical analysis were transformed into arcsine $(\mathrm{X})$; SD: standard deviation.

Thaumetopoea pityocampa Den. \& Schiff (Sevim et al., 2010). Entomopathogenic fungi have a number of determinants of pathogenicity, including production of cuticle-degrading enzymes, such as proteases, chitinases and lipases (Bidochka and Khachatourians, 1987). These enzymes are pointed out as important in the infection process, since they have already hydrolyzed polymer protein and chitin complexes, the major components of the insect's cuticle (St. Leger et al., 1986).

The best model to determining the level of pathogennicity in entomopathogenic fungi is based on a protease of the subtilisin-like, called Pr1, first studied in $M$. anisopliae by St. Leger et al. (1988). A trypsin-like enzyme (Pr2) belonging to the serine protease group also occurs during the early stages of cuticle colonization suggesting that it plays a hole in degrading extracellular proteins complementary to that of Pr1 (St. Leger et al., 1996).

Gupta et al. (1994) have shown a correlation between the production of high levels of chitinases and proteases and the virulence of $B$. bassiana against Gallera mellonela L. and Trichoplusia ni Hubner. In addition, Fang et al. (2005) proved that an overexpression of a chitinase gene (Bbchit1) enhanced the virulence of $B$. bassiana to aphids (Myzus persicae Sulzer), compared with a wild-type strain.

Only a few papers have focused on the production of these enzymes by $B$. bassiana strains on the presence of host's cuticle. Campos et al. (2005) have detected the presence of chitinases and proteases in the cuticle of Boophilus microplus Canestrini. In addition, Dias et al. (2008) and Montesinos-Matías et al. (2011) evaluated the production of $\operatorname{Pr} 1$ after growing the fungus in the presence of coffee-borer cuticle Hypothenemus hampei Ferrari and Tenebrio molitor L., respectively. These works suggest that the enzymes from $B$. bassiana were expressed differently according to the type of insect cuticle and there are not reports about the production of
$\operatorname{Pr} 1, \operatorname{Pr} 2$ and chitinases in medium supplemented with $D$. saccharalis cuticle, important pest in sugarcane. The pathogenicity of $B$. bassiana strains were studied in order to verify if there is a correlation between the production of these enzymes and the virulence, contributing to the understanding of the parasite-host relation and to the selection of $B$. bassiana strains for biological control of $D$. saccharalis.

The objectives of this study were: (1) evaluate the pathogenicity of $B$. bassiana strains against $D$. saccharalis (2) investigate the production of proteases and chitinase by $B$. bassiana in the presence of the cuticle of sugarcane borer; and, (3) evaluate the relationship between the production of enzymes and pathogenicity of the strains.

\section{MATERIAL AND METHODS}

\section{Diatraea saccharalis larvae}

The second instar larvae of $D$. saccharalis were obtained from the Sugarcane Experimental Station of Carpina/Federal Rural University of Pernambuco/Brazil and were maintained with artificial diet, which basically consists in a solution of vitamins, sugar, soy meal, wheat germ, ascorbic acid and water, according to the protocol of Hensley and Hammond (1968). However, $24 \mathrm{~h}$ before the bioassays, each larva was confined individually in plastic containers $(17 \times 21 \times 25 \mathrm{~cm})$ with sugarcane stalks as the food source.

\section{Reactivated inoculum}

The $B$. bassiana sensu latu strains isolated originally from different hosts were supplied by Micoteca URM (University Recife Micology/UFPE) (Table 1). To reactivate the strains, they were inoculated in Petri dishes containing potato dextrose agar plus chloramphenicol $(0.05 \% \mathrm{v} / \mathrm{v})$, supplemented with $0.5 \%$ of yeast extract (PDAY) and incubated at $26^{\circ} \mathrm{C}$ for 12 days for conidiation. Following incubation, conidia harvest were prepared in $0.01 \% \mathrm{v} / \mathrm{v}$ Tween 80 in sterilized distilled water and were sprayed through the 
use of micro-atomizer brand Paasche "VL" on ten D. saccharalis until insect death. Newly emerged conidia from the insect were subcultured not more than four times, at ten days intervals in PDAY and used to prepare the reactivated inoculum suspension containing $10^{8}$ conidia/ml (Ito et al., 2007). To confirm viability, the conidia were spread on PDAY and incubated for $16 \mathrm{~h}$ at $26^{\circ} \mathrm{C}$. Germination rates were scored at $400 \times$ magnification by observing under microscope, at random, 100 conidia for the presence of germ tubes. Germination was at least $90 \%$ throughout the study.

\section{Screening bioassay protocol}

The basic measure of virulence generated in this study was the mortality recorded seven days post-inoculation. To assess infection, $D$. saccharalis larvae were placed in a sterile Petri dish $(9 \mathrm{~cm}$ in diameter) and then sprayed with $1 \mathrm{ml}$ of the reactivated inoculum suspension, as per as per reported in item Reactivated inoculum. The control group was sprayed, with sterile water containing $100 \mu \mathrm{l}$ of Tween 80 (Tefera and Pringle, 2003). The design was completely randomized, with 11 treatments (10 strains of $B$. bassiana + Control).

For each treatment, five containers were used, each containing 10 larvae. The observations were taken daily for a period of seven days and larvae died were removed daily. To confirm the mortality by the fungus, the dead larvae were immediately surface sterilized with $70 \%$ alcohol for $10 \mathrm{~s}$, followed in $1 \%$ sodium hypoclorite for 3 min and three rinses with sterile distilled water, placed on sterile wet filter paper in sterile Petri dishes. Mortality due the fungus was confirmed by microscopic examination of hyphae and spores on the surface of the cadaver.

\section{Enzyme assays}

$B$. bassiana strains that showed higher mortality against $D$. saccharalis (Table 1) and higher conidia production were selected for testing to enzyme production. A suspension containing $1 \times 10^{6}$ conidia/ml was inoculated in $30 \mathrm{ml}$ of the minimal liquid medium (MM) (Pontecorvo et al., 1953) as control and was inoculated in $\mathrm{MM}+$ cuticle (MM + CUT): MM lacking a source of nitrogen and of glucose but with the addition of cuticle from larvae of $D$. saccharalis $(0.5 \%) \mathrm{w} / \mathrm{v}$. The larvae were dissected with a scalpel under an ocular for removal of the viscera and the cuticle was then ovendried at $65^{\circ} \mathrm{C}$ for $1 \mathrm{~h}$. After that, the cuticle was prepared using a solution of $0.2 \mathrm{M}$ potassium tetra-borate and sterilized with water vapor without pressure. After, it was added to previously sterilized $\mathrm{MM}\left(121^{\circ} \mathrm{C}\right.$ for $\left.15 \mathrm{~min}\right)$ and again sterilized with water vapor without pressure for $5 \mathrm{~min}$ (Dias et al., 2008).

Cultures were incubated at $28^{\circ} \mathrm{C}$ and maintained under agitation (180 rpm) out to 24, 48, 72 and $96 \mathrm{~h}$. After incubation, each culture was centrifugated at $8000 \mathrm{~g}$ for $15 \mathrm{~min}$ at $4^{\circ} \mathrm{C}$ to separate the mycelium and the supernatant obtained was stored at $-20^{\circ} \mathrm{C}$ for enzyme assays. The design was completely randomized, in a factorial scheme $3 \times 4$ ( 3 strains $\times 4$ incubation times), for a total of 12 treatments, with two repetitions. The subtilisin-like (Pr1) and trypsin-like (Pr2) activities were assayed using N-Suc-(Ala) ${ }_{2}$-ProPhe-p-nitroanilide and N-benzoyl-Phe-Val-Arg-p-nitroanilide (Sigma, St. Louis, MO) as substrates, respectively. Each assay consisted of $0.05 \mathrm{ml} 1 \mathrm{mM}$ substrate, $0.1 \mathrm{ml}$ enzyme sample, and $0.85 \mathrm{ml} 15 \mathrm{mM}$ Tris- $\mathrm{HCl}, \mathrm{pH}$ 8.0. The mixture was incubated for 30 min at $28^{\circ} \mathrm{C}$ and the reaction was stopped by adding $0.25 \mathrm{ml}$ of $30 \%$ acetic acid and left to stand for $15 \mathrm{~min}$ in ice, after which samples were centrifuged at $1250 \mathrm{~g}$ for $5 \mathrm{~min}$ at $4^{\circ} \mathrm{C}$. The supernatants were compared at $410 \mathrm{~nm}$. One unit of enzyme activity (U) was defined as the amount of the enzyme able to release $1 \mu \mathrm{m}$ of nitroanilide (NA) per milliliter per second at $28^{\circ} \mathrm{C}$ (Donatti et al., 2008).
Chitinase activity was assayed by the method of Nahar et al. (2004). The reaction mixture containing $1 \mathrm{ml}$ of $1 \%$ colloidal chitin and $0.5 \mathrm{ml}$ of supernatant solution was incubated for $1 \mathrm{~h}$ at $50^{\circ} \mathrm{C}$ and the reaction was stopped by immersion in a bath of boiling water for $1 \mathrm{~min}$. After centrifugation, $250 \mu \mathrm{L}$ from the supernatant fluid was incubated with $50 \mu \mathrm{l}$ of $0.8 \mathrm{M}$ sodium tetra-borate, $\mathrm{pH} 8.0$ at $100^{\circ} \mathrm{C}$ for $3 \mathrm{~min}$. After the mixture was cooled, $1.5 \mathrm{ml}$ of $\mathrm{p}$ dimethyl aminobenzaldehyde (DMAB) solution (1 $\mathrm{g}$ of DMAB dissolved in $100 \mathrm{ml}$ of glacial acetic acid containing $1 \% \mathrm{v} / \mathrm{v}$ hydrochloric acid) was added and the mixture was incubated for 20 min at $37^{\circ} \mathrm{C}$. Absorbance at $585 \mathrm{~nm}$ was measured against water as a blank. One unit of chitinase activity was defined as the amount of enzyme which produced sugars equivalent to $1 \mu \mathrm{mol}$ of $N$ acetylglucosamine per min under the conditions described above.

\section{Statistical analysis}

Percent mortality was corrected for control mortality (SchneiderOrelli, 1947) and normalized by arcsine (X) transformation before being subjected to analysis of variance (ANOVA). The Tukey test analysis was used to separate the means as a post-ANOVA procedure $(p<0.05)$. Enzyme production data were subjected to the analysis of variance (ANOVA). The averages of the characteristics evaluated in response to the qualitative factor (strains) were subjected to Tukey test at $5 \%$ probability. These statistical analyses were performed using the ASSISTAT 7.5 beta software (Silva and Azevedo, 2002). Pearson's Correlation Coefficient was used to check the level of correlation between mortality caused by each strains and enzyme activity and it was calculated using enzyme's production at $96 \mathrm{~h}$ and mortality rate at $96 \mathrm{~h}$ post-inoculation. The analysis was performed using BioEstat software system, version 5.3.

\section{RESULTS}

\section{Screening bioassay}

Results of the screening assays are presented in Table 1. Mean mortality in the control was $5.4 \%$ seven days after the treatment. All the fungal isolates were pathogenic to larvae of $D$. saccharalis and there were significant differences in mortality between fungal isolates $(F=75.26$; $d f: 10 ; p<0.01)$. The mortality ranged from 36 to $88 \%$ (Table 1). Three strains caused mortality above $80 \%$ (URM2915, URM2921 and URM3447), while the URM2924, URM2912 and URM4548 caused below 50\%. B. bassiana URM2915 is most indicated for the control of D. saccharalis because besides causing high mortality also showed good conidial production, fundamental characteristics to be used in programs for biological pest control.

\section{Production of subtilisin-like and trypsin-like enzymes and chitinase in the presence of the cuticle of sugarcane borer}

Based on the mortality rate (Table 1 ) and characteristics, like the production of conidia (data not shown), three strains were selected for production testing of Pr1, Pr2 and chitinase. The production of these enzymes was determined after the growth of the strains (URM2915, 
Table 2. Factorial analysis of the strains, culture media and incubation times in the production of proteases (Pr1 and Pr2) and chitinases by Beauveria bassiana in the presence of Diatraea saccharalis cuticle.

\begin{tabular}{lccccccccc}
\hline \multirow{3}{*}{ Factor } & \multicolumn{4}{c}{ Pr1 } & \multicolumn{4}{c}{ Pr2 } & \multicolumn{3}{c}{ Chitinase } \\
\cline { 2 - 10 } & $\boldsymbol{d}$ & $\begin{array}{c}\text { Mean } \\
\text { square }\end{array}$ & $\boldsymbol{F}$ & $\boldsymbol{d f}$ & $\begin{array}{c}\text { Mean } \\
\text { square }\end{array}$ & $\boldsymbol{F}$ & $\boldsymbol{d}$ & $\begin{array}{c}\text { Mean } \\
\text { square }\end{array}$ & $\boldsymbol{F}$ \\
\hline Strains (S) & 2 & 78.77 & $2.55^{*}$ & 2 & 0.357 & $0.45^{\star}$ & 2 & 46.68 & $27.81^{*}$ \\
Culture media (CM) & 1 & 2020.5 & $654.82^{*}$ & 1 & 6441.5 & $8257.4^{*}$ & 1 & 2062.5 & $1228.7^{*}$ \\
Time (T) & 3 & 3881.5 & $125.82^{*}$ & 3 & 556.5 & $713.45^{*}$ & 3 & 318.55 & $189.77^{*}$ \\
$\mathrm{~S} \times \mathrm{CM}$ & 2 & 238.8 & $7.74^{*}$ & 2 & 0.35 & $0.45^{*}$ & 2 & 52.27 & $31.13^{*}$ \\
$\mathrm{~S} \times \mathrm{T}$ & 6 & 13.97 & 0.45 & 6 & 4.75 & $6.09^{*}$ & 6 & 2.89 & 1.72 \\
$\mathrm{CM} \times \mathrm{T}$ & 3 & 2490.9 & $80.74^{*}$ & 3 & 556.55 & $713.4^{*}$ & 3 & 287.60 & $171.3^{*}$ \\
$\mathrm{~S} \times \mathrm{CM} \times \mathrm{T}$ & 6 & 35.27 & 1.14 & 6 & 4.75 & 6.09 & 6 & 2.29 & 1.36 \\
\hline
\end{tabular}

*Significant to the $99 \%$ level of probability $(p<0.01) ;{ }^{a} d f$ : degree of freedom.

Table 3. Subtilisin-like ( $\operatorname{Pr} 1)$ activity $(\mathrm{U} / \mathrm{ml})$ in supernatant cultures of Beauveria bassiana grown in minimal medium (MM) and minimal medium plus Diatraea saccharalis cuticle (MM+CUT) ${ }^{a}$

\begin{tabular}{lcccccccc}
\hline \multirow{2}{*}{ Strain } & \multicolumn{2}{c}{$\mathbf{2 4} \mathbf{h}$} & \multicolumn{2}{c}{$\mathbf{4 8} \mathbf{h}$} & \multicolumn{2}{c}{$\mathbf{7 2} \mathbf{h}$} & \multicolumn{2}{c}{$\mathbf{9 6} \mathbf{h}$} \\
\cline { 2 - 9 } & $\mathbf{M M}$ & $\mathbf{M M + C U T}$ & $\mathbf{M M}$ & $\mathbf{M M + C U T}$ & $\mathbf{M M}$ & $\mathbf{M M + C U T}$ & $\mathbf{M M}$ & MM+CUT \\
\hline URM2915 & 0 & $1.53 \pm 0.04$ & 0 & $46.83 \pm 0.08$ & $0.83 \pm 0.02$ & $68.83 \pm 0.19$ & $2.92 \pm 0$ & $70.79 \pm 0.19$ \\
URM2930 & 0 & $0.55 \pm 0.01$ & 0 & $45.16 \pm 0.2$ & 0 & $73.74 \pm 0.12$ & $3.4 \pm 0.01$ & $70.46 \pm 0.04$ \\
URM4548 & 0 & $1.04 \pm 0.02$ & $15.26 \pm 0.24$ & $40.70 \pm 0.57$ & $15.89 \pm 0.17$ & $68.70 \pm 0.40$ & $17 \pm 0.26$ & $66.70 \pm 0.25$ \\
\hline
\end{tabular}

${ }^{\mathrm{a}} \mathrm{The} \operatorname{Pr} 1$ activities are means standard errors of the means based on three replicates.

Table 4. Trypsin-like (Pr2) activity $(\mathrm{U} / \mathrm{ml})$ in supernatant cultures of Beauveria bassiana grown in minimal medium (MM) and minimal medium plus Diatraea saccharalis cuticle $(\mathrm{MM}+\mathrm{CUT})^{\mathrm{a}}$.

\begin{tabular}{|c|c|c|c|c|c|c|c|c|}
\hline \multirow{2}{*}{ Strain } & \multicolumn{2}{|r|}{$24 \mathrm{~h}$} & \multicolumn{2}{|r|}{$48 \mathrm{~h}$} & \multicolumn{2}{|r|}{$72 \mathrm{~h}$} & \multicolumn{2}{|r|}{$96 \mathrm{~h}$} \\
\hline & MM & $\mathrm{MM}+\mathrm{CUT}$ & MM & $\mathrm{MM}+\mathrm{CUT}$ & MM & $\mathrm{MM}+\mathrm{CUT}$ & MM & $\mathrm{MM}+\mathrm{CUT}$ \\
\hline URM2915 & 0 & $1.95 \pm 0.01$ & 0 & $26.83 \pm 0.06$ & 0 & $30.04 \pm 0.01$ & 0 & $35.12 \pm 0.04$ \\
\hline URM2930 & 0 & $1.46 \pm 0.04$ & 0 & $25.71 \pm 0.08$ & 0 & $30.59 \pm 0.07$ & 0 & $34.71 \pm 0.04$ \\
\hline URM4548 & 0 & $6.41 \pm 0.01$ & 0 & $25.16 \pm 0.14$ & 0 & $29.34 \pm 0.04$ & 0 & $30.66 \pm 0.00$ \\
\hline
\end{tabular}

${ }^{\mathrm{a}}$ The Pr2 activities are means standard errors of the means based on three replicates.

URM2930 and URM4548) in liquid medium in the presence and absence of cuticle of $D$. saccharalis. All strains of $B$. bassiana produced Pr1 and Pr2 in MM+CUT and there were significant differences between the strains (Table 2). For each of the three strains, Pr1 activity was detected at $24 \mathrm{~h}$ of growth. For URM2930 and URM4548, the peak of activity was observed at $72 \mathrm{~h}$ of growth. In the MM, Pr1 activity was detected at $48 \mathrm{~h}$ for URM4548, at $72 \mathrm{~h}$ for URM2915 and at $96 \mathrm{~h}$ of incubation only for the $B$. bassiana URM2930 (Table 3). Similarly, PR2 activity was detected at $24 \mathrm{~h}$ of incubation in the MM + CUT, and the peak of the activity was observed at $96 \mathrm{~h}$. It was not possible to detect activity in the medium containing nitrate as the sole nitrogen source
(MM) (Table 4). As shown in Tables 3 and 4, the strains studied showed higher levels of production of Pr1 than Pr2, highlighting URM2930 in production of Pr1 (73.74 $\mathrm{U} / \mathrm{ml}$ ) and URM2915 in production of PR2 $(35.12 \mathrm{U} / \mathrm{ml})$.

Chitinase activity was detected at $24 \mathrm{~h}$ of incubation on MM+CUT and at $72 \mathrm{~h}$ on MM for URM2915 and URM4548. The amount of secreted enzymes varied between the stains and the highest activity was observed for $B$. bassiana URM2915 strain $(28.93 \mathrm{U} / \mathrm{ml})$ at $96 \mathrm{~h}$. Enzyme activity was investigated for a period of $96 \mathrm{~h}$ and the highest chitinase activity was observed on the last time in the two culture media (Table 5). However, the chitinase activity was higher in MM + CUT at all incubation times compared to activities on MM. 
Table 5. Chitinolytic activity $(\mathrm{U} / \mathrm{ml})$ in supernatant cultures of Beauveria bassiana grown in minimal medium (MM) and minimal medium plus Diatraea saccharalis cuticle $(\mathrm{MM}+\mathrm{CUT})^{\mathrm{a}}$.

\begin{tabular}{lcccccccc}
\hline \multirow{2}{*}{ Strain } & \multicolumn{2}{c}{$\mathbf{2 4} \mathbf{~}$} & \multicolumn{2}{c}{$\mathbf{4 8}$} & \multicolumn{2}{c}{$\mathbf{7 2} \mathbf{~}$} & \multicolumn{2}{c}{$\mathbf{9 6 ~ h}$} \\
\cline { 2 - 9 } & $\mathbf{M M}$ & $\mathbf{M M + C U T}$ & $\mathbf{M M}$ & $\mathbf{M M + C U T}$ & $\mathbf{M M}$ & $\mathbf{M M + C U T}$ & $\mathbf{M M}$ & $\mathbf{M M + C U T}$ \\
\hline URM2915 & 0 & $3.70 \pm 0.2$ & 0 & $14.21 \pm 0.4$ & $0.17 \pm 0$ & $22.2 \pm 0.7$ & $0.59 \pm 0.0$ & $28.93 \pm 0.1$ \\
URM2930 & 0 & $0.17 \pm 0.0$ & 0 & $10.01 \pm 0.4$ & 0 & $16.73 \pm 0.1$ & 0 & $22.2 \pm 0.2$ \\
URM4548 & 0 & $0.17 \pm 0.0$ & 0 & $4.54 \pm 0.1$ & $1.01 \pm 0.02$ & $15.05 \pm 0.1$ & $1.01 \pm 0.01$ & $22.2 \pm 0.2$ \\
\hline
\end{tabular}

${ }^{a}$ The chitinase activities are means standard errors of the means based on three replicates.

There was significant interaction among the strains and culture media in the production of the enzymes and there were also interaction between culture media and incubation time in the production of proteases and chitinase (Table 2). These interactions were caused by the fact that enzyme activity was highest in medium containing cuticle and increased with the length of incubation. Correlation analysis between the percentage of mortality by three $B$. bassiana strains and $\operatorname{Pr} 1(r$ $=0.8207 ; P=0.0453)$ and $P r 2(r=0.8133 ; P=0.049)$ activity suggests a positive correlation of these variables in the medium containing cuticle. However there was no correlation with the chitinase activity $(r=-0.0008$; $\mathrm{P}=0.9987)$.

\section{DISCUSSION}

Although all the 10 fungal isolates tested were pathogenic to $D$. saccharalis, there were significant variations amongst the isolates. These variations have been reported in many arthropod pests (Bugeme et al., 2009; Godonou et al., 2009; Abood et al., 2010; Sevim et al., 2010) and emphasizes the need of screening for strain selection. The results were similar to those of Wraight et al. (2010). These authors evaluated virulence of $B$. bassiana against different species of Lepidoptera and observed that mortality was high and varied positively among the 43 isolates used, thus showing the potential of the fungus against different pests. Kaur and Padmaja (2008) evaluated the action of $23 \mathrm{~B}$. bassiana isolates, obtained from different hosts and regions, against Spodoptera litura Fabricius and verified that pathogenicity varied among them, but there was no correlation between the variability and the host's geographic origin, as observed in this work.

The insect cuticle forms an effective barrier against organisms lacking an active cuticle penetration mechanism (virus, bacteria and protozoa). Only entomo-pathogenic fungus can penetrate their hosts through the cuticle, using physical and/or enzymatic mechanisms (St. Leger, 1995). In this paper was studied the production of the enzymes involved in the process of infection, in three strains of $B$. bassiana in the presence of $D$. saccharalis cuticle. We observed that when cuticle was added to the medium, there was an increase in production of Pr1 and
Pr2, indicating that this was stimulated by cuticle components. By contrast, Tiago et al. (2002) demonstrated that $M$. flavoviride CG423 (syn. M. anisopliae var. acridum) has high levels of Pr2 only in minimal liquid medium without cuticle, with other negative effects being found in the presence of cuticle of Schistocerca pallens Thunberg.

In this study, production of Pr1 was higher as compared to Pr2, however the peaks of activity were the same (85 h), suggesting that there are different regulatory systems for these enzymes. Donatti et al. (2008) emphasized that the differences in the production of enzymes may reflect different functions in the infection process. In addition, both proteases were produced at $24 \mathrm{~h}$ of incubation in medium containing cuticle, suggesting their expression is not coordinated in this fungus. Similar data was observed in $B$. bassiana grown in $H$. hampei cuticle (Dias et al., 2008). Differently, Paterson et al. (1994) reported that Pr2 occurs before and would be involved in the activation or induction of Pr1 in M. anisopliae var. anisopliae. Differences between fungus species reveal that a complex mechanism is involved in the production of cuticle-degrading proteases.

Chitinase production by $B$. bassiana URM2915, URM2930 and URM4548 was higher during the last days of incubation in the medium containing cuticle as the sole source of carbon. The enhancing effect of cuticle on chitinase production suggests that this enzyme may be specifically induced by a cuticular component.

Studies have evaluated the effects of different sources of carbon in the production of this enzyme and observed that when the fungus was grown in medium with cuticle and glucose, production was lower than in medium containing only cuticle (Campos et al., 2005), and that there was repression of the enzyme when a easily available carbon source, glucose, was added to the medium (Dhar and Kaur, 2010). Chitinase production was lower than Pr1 and PR2 production, which can be explained by the composition of the insect's cuticle, a composite material consisting of arrangements of highly crystalline chitin nanofibers embedded in a matrix of protein (Vincent and Wegst, 2004). As reported by Fang et al. (2009), B. bassiana transformants secreting the fusion protein (protease and chitinase gene) penetrated the cuticle significantly faster than the wild type or transformants overexpressing either chitinase or protease 
gene.

As reported in the literature, the production of cuticledegrading enzymes is one of the pre-requisites for fungal infection (Mustafa and Khaur, 2010), and demonstrates the relation between production and virulence that has been targeted by several investigations. The current study has provided evidence for the relationship between enzyme production and virulence of $B$. bassiana against $D$. saccharalis. According to our results, Gupta et al. (1994) showed that levels of production of Pr1, Pr2 and NAGase (chitinase) have been related to virulence parameters in $B$. bassiana.

Moreover, Kim et al. (2010) showed that from the bioassay with the enzyme-inhibited supernatants processed by substrate inhibition, decreased aphicidal activities were observed for all three enzyme-inhibited treatments. This finding provides evidence that the enzymes ( $\operatorname{Pr} 1$, Pr2 and most particularly the chitinase) in the supernatant of $B$. bassiana were strongly involved in the aphicidal activity.

Pelizza et al. (2011) screened 28 isolates of $B$. bassiana and nine isolates of $M$. anisopliae for chitinase production in solid medium and the results suggest a direct relationship between a high chitinolytic activity and an efficient virulence of the fungal strain against the tested insect pest (Tropidacris collaris Stoll). On the other hand, Silva et al. (2005) tested the larvicidal effect of $M$. anisopliae isolates against Aedes aegypti L. and the isolates showed a high variability of total protein production and NAGase activity after 48 and $72 \mathrm{~h}$ incubation in MM, but no relationship between enzyme levels and insecticidal activity could be detected, suggesting that other factors may be involved in the process.

The results presented in this study reveal that laboratory bioassays are a relevant stage in selecting the most efficient strains for controlling pests. The pathogenicity of $B$. bassiana can be influenced by strain used. These studies confirm that the production of cuticle-degrading enzymes by $B$. bassiana is influenced by specific components of the cuticle of $D$. saccharalis. This paper showed that there was a relationship between enzyme production and pathogenicity of $B$. bassiana, but many factors interfere directly in this process and more research is needed about this complex mechanism.

\section{ACKNOWLEDGMENTS}

The authors thank Conselho Nacional de Desenvolvimento Científico e Tecnológico (CNPq) for financial support, Dr. David Bousfield for reviewing the manuscript and Venézio Santos for the statistical analysis.

\section{REFERENCES}

Abood F, Bajwa GA, Ibrahim YB, Sajap AS (2010). Pathogenicity of
Beauveria bassiana against the Tiger Moth, Atteva sciodoxa (Lepidoptera:Yponomeutidae). J. Entomol. 7:19-32.

Alves SB, Rossi LS, Lopes RB, Tamai MA, Pereira RM (2002). Beauveria bassiana yeast phase on agar medium and its pathogenicity against Diatraea saccharalis (Lepidoptera: Crambidae) and Tetranychus urticae (Acari: Tetranychidae). J. Invertebr. Pathol. 81:70-77.

Bidochka MJ, Khachatourians GG (1987). Purification and properties of an extracellular protease produced by Beauveria bassiana. Appl. Environ. Microbiol. 53:1679-1684.

Bugeme DM, Knapp M, Boga HI, Wanjoya AK, Maniana NK (2009). Influence of Temperature on Virulence of Fungal Isolates of Metarhizium anisopliae and Beauveria bassiana to the Two-Spotted Spider Mite Tetranychus urticae. Mycopathologia 167:221-227.

Campos RA, Arruda W, Boldo JT, Silva MV, Barros NM, Azevedo JL, Schrank A, Vainstein, MH (2005). Boophilus microplus Infection by Beauveria amorpha and Beauveria bassiana: SEM Analysis and regulation of Subtilisin-like Proteases and Chitinases. Curr. Microbiol. 50:257-261.

Dhar P, Kaur G (2010). Effects of carbon and nitrogen sources on the induction and repression of chitinase enzyme from Beauveria bassiana isolates. Afr. J. Biotechnol. 9:8092-8099.

Dias BA, Neves PMOJ, Furlaneto-Maia L, Furlaneto MC (2008). Cuticledegrading proteases produced by the entomopathogenic fungus Beauveria bassiana in the presence of coffee berry borer cuticle. Braz. J. Microbiol. 39:301-306.

Donatti AC, Furlaneto-Maia L, Fungaro MHP, Furlaneto MC (2008). Production and regulation of cuticle-degrading proteases from Beauveria bassiana in the presence of Rhammatocerus schistocercoides cuticle. Curr. Microbiol. 56:256-260.

Fang W, Feng J, Fan Y, Zhang Y, Bidochka MJ, St. Leger RJ, Pei Y (2009). Expressing a fusion protein with protease and chitinase activities increases the virulence of the insect pathogen Beauveria bassiana. J. Invertebr. Pathol. 102:155-159.

Fang W, Leng B, Xiao Y, Jin K, Ma J, Fan Y, Feng J, Yang X, Zhang Y, Pei $Y$ (2005). Cloning of Beauveria bassiana chitinase gene Bbchit1 and its application to improve fungal strain virulence. Appl. Environ. Microbiol. 71:363-370.

Gallo D, Nakano O, Silveira Neto S, Carvalho RPL, Batista GC de, Berti Filho, Parra JRP, Zucchi RA, Alves SB, Vendramim JD, Marchini LC, Lopes JRS, Omoto C (2002). Manual de Entomologia Agrícola. 3th edition. Piracicaba, FEALQ.

Godonou BJ, Atcha-Ahowe' C, Vodouhe' S, Kooyman C, Ahanche' de'A, Korie S (2009). Potential of Beauveria bassiana and Metarhizium anisopliae isolates from Benin to control Plutella xylostella L. (Lepidoptera: Plutellidae). Crop. Prot. 28:220-224.

Gupta SC, Leathers TD, El-Sayed GN, Ignoffo CM (1994). Relationships among enzyme activities and virulence parameters in Beauveria basiana infections of Galleria mellonella and Trichoplusia ni. J. Invertebr. Pathol. 64:13-17.

Hajek AE, Delalibera Jr I (2010). Fungal pathogens as classical biological control agents against arthropods. BioControl 55:147-158.

Hensley SD, Hammond AH (1968). Laboratory techniques for rearing the sugarcane borer on an artificial diet. J. Econ. Entomol. 61:17421743.

Ito ET, Varéa-Pereira G, Miyagui DT, Pinotti MHP, Neves PMOJ (2007). Production of Extracellular Protease by a Brazilian Strain of Beauveria bassiana Reactivated on Coffee Berry Borer, Hypothenemus hampei. Braz. Arch. Biol. Technol. 50:217-223.

Kaur G, Padmaja V (2008). Evaluation of Beauveria bassiana isolates for virulence against Spodoptera litura (Fab.) (Lepidoptera: Noctuidae) and their characterization by RAPD-PCR. Afr. J. Microbiol. Res. 2:299-307.

Kim JS, Roh JY, Choi JY, Wang Y, Shim HJ, Je YH (2010). Correlation of the aphicidal activity of Beauveria bassiana SFB-205 supernatant with enzymes. Fungal. Biol. 114:120-128.

Lacey LA, Frutos R, Kaya HR, Vail P (2001). Insect Pathogens as Biological Control Agents: Do They Have a Future? Biol. Control 21:230-248.

Lewis LC, Bruck DJ, Gunnarson RD (2002). Gunnarson, R.D. On-farm evaluation of Beauveria bassiana for control of Ostrinia nubilalis in Iowa, USA. BioControl. 47:167-176. 
Montesinos-Matías R, Viniegra-González G, Alatorre-Rosas R, Loera O (2011). Relationship between virulence and enzymatic profiles in the cuticle of Tenebrio molitor by 2-deoxy-D-glucose-resistant mutants of Beauveria bassiana (Bals.) Vuill. World J. Microbiol. Biotechnol. 27:2095-2102.

Mustafa U, Kaur G (2010). Studies on Extracellular Enzyme Production in Beauveria Bassiana Isolates. Int. J. Biotech. Biochem. 6:701-713.

Nahar P, Ghormade V, Deshpande MV (2004). The extracellular constitutive production of chitin deacetylase in Metarhizium anisopliae: possible edge to entomopathogenic fungi in the biological control of insect pests. J. Invertebr. Pathol. 85:80-88.

Oliveira, MAP, Marques, EJ, Wanderley-Teixeira, Barros R (2008). Efeito de Beauveria bassiana (Bals.) Vuill. e Metarhizium anisopliae (Metsch.) Sorok. sobre características biológicas de Diatraea sacharalis F. (Lepidoptera: Crambidae). Acta. Scient. Biol. Sci. 30:220-224.

Paterson IC, Charnley AK, Cooper RM, Clarkson M (1994). Partial characterization of specific inducers of a cuticle-degrading protease from the insect pathogenic fungus Metarhizium anisopliae. Microbiology 140:3153-3159.

Pelizza SA, Elíades LA, Saparrat MCN, Cabello MN, Scorsetti AC, Lange CE (2011). Screening of Argentine native fungal strains for biocontrol between fungal pathogenicity and chitinolytic enzyme activity. World J. Microbiol. Biotechnol. 28(4):1359-1366.

Pontecorvo G, Oper JA, Hemmons LM, MacDonald KD, Bufton AWJ (1953). The genetics of Aspergillus nidulans. Adv. Genet. 5:141-238.

Schneider-Orelli O (1947). Entomoligisches praktikum. Aarau: Sauerlander, 1947. pp.149.

Sevim A, Demir I, Demirbag E (2010). Molecular characterization and virulence of Beauveria spp. from the pine processionary moth, Thaumetopoea pityocampa (Lepidoptera: Thaumetopoeidae). Mycophatologia 170:269-277

Silva ASF de, Azevedo CAV de (2002). Versão do programa computacional Assistat para o sistema operacional Windows. Ver. Bras. Prod. Agro. 4:71-78.

Silva RO, Silva HHG, Ulhoa CJ, Luz C (2005). Is there a relationship between $N$-acetyl- $\beta$-D-glucosaminidase activity of Metarhizium anisopliae (Metschn.) Sorokin (Hyphomycetes) isolates from peridomestic areas in Central Brazil and larvicidal effect on Aedes aegypti (L.) (Diptera, Culicidae)?. J. Appl. Entomol. 129:158-164.
Silva VCA, Barros R, Marques EJ, Torres JB (2003). Suscetibilidade de Plutella xylostella (L.) (Lepidoptera: Plutellidae) aos fungos Beauveria bassiana (Bals.) Vuill. e Metarhizium anisopliae (Metsch.) Sorok. Neotrop. Entomol. 32:653-658.

St Leger RJ, Joshi L, Bidochka MJ, Rizzo NW, Roberts DW (1996). Biochemical characterization and ultrastructural localization of two extracellular trypsins produced by Metarhizium anisopliae in infected insect cuticles. Appl. Environ. Microbiol. 62:1257-1264.

St. Leger RJ (1995). The role of cuticle-degrading proteases in fungal pathogenesis of insects. Can. J. Bot. 73:1119-1125.

St. Leger RJ, Cooper RM, Charnley AK (1986). Cuticle-degrading enzymes of entomopathogenic fungi: Cuticle degradation in vitro by enzymes from entomopathogens. J. Invertebr. Pathol. 47:167-177.

St. Leger RJ, Durrands PK, Cooper RM, Charnley AK (1988). Regulation of production of proteolytic enzymes by entomopathogenic fungus Metarhizium anisopliae. Arch. Microbiol. 150:413-416.

Tefera T, Pringle KL (2003). Effect of exposure method to Beauveria bassiana and conidia concentration on mortality, mycosis, and sporulation in cadavers of Chilo partellus (Lepidoptera: Pyralidae). J. Invertebr. Pathol. 84:90-95.

Tiago PV, Fungaro MHP, Furlaneto MC (2002). Cuticle degrading proteases from the entomopathogen Metarhizium flavoviride and their distribution in secreted and intracellular fractions. Lett. Appl. Microbiol. 34:91-94.

Vijayavani S, Reddy KRK, Murthy GBVN (2009). Pathogenicity of Beauveria bassiana (Deuteromycotina: Euteromycotina: Hyphomycetes) strains on Spodoptera litura (Fab.) J. Biopest. 2:205207.

Vincent JFV, Wegst UGK (2004). Design and mechanical properties of insect cuticle. Arth. Struct. Dev. 33:187-199.

Wraight SP, Ramos ME, Avery PB, Jaronski ST, Vandenberg JD (2010). Comparative virulence of Beauveria bassiana isolates against lepidopteran pests of vegetable crops. J. Invertebr. Pathol. 103:186199. 